\title{
THE TREATMENT OF ACUTE ALCOHOLISM WITH GLUCOSE AND INSULIN
}

\author{
By WALTER GOLDFARB, KARL M. BOWMAN, AND SAM PARKER
}

\author{
With THE tECHNICAL ASSISTANCE OF B. KRAUTMAN \\ (From the Psychiatric Divisions, Bellevue Hospital and Kings County Hospital, \\ New York City)
}

(Received for publication May 5, 1939)

The disposal of alcohol in the body has been a subject of wide interest and numerous publications. It is generally agreed that two methods are available to the body, excretion and oxidation. Sollman (1) states that from 2 to 10 per cent of the ingested alcohol is excreted by the lungs and kidneys, while the remainder is oxidized (2). Haggard and Greenberg (3) found that 2.1 to 4.3 per cent was excreted through the kidneys and 3.94 per cent through the respiratory system. Robinson and Selesnick (4) administered a mixture of 10 per cent carbon dioxide and 90 per cent oxygen to patients for one-half hour. The increased respiratory ventilation resulted in an appreciable decrease in blood alcohol and the patients showed a marked clinical improvement.

The major portion of the ingested alcohol is disposed of by oxidation. Mellanby (5) found that the ingestion of food with alcohol resulted in a lower blood concentration of alcohol. Southgate (6) demonstrated a reduction of blood alcohol after food ingestion and ascribed it to a specific effect of the food on the disappearance of the alcohol as well as a decreased absorption from the gastro-intestinal tract. Widmark (7) found that the ingestion of amino acids particularly lowered the blood alcohol, while glucose had no effect. The ingestion of alcohol with glucose resulted in a lower respiratory quotient than the ingestion of glucose alone $(8,9,10)$. The latter authors also showed that the blood alcohol was more rapidly decreased when glucose was administered. Clark and Morrissey (11) measured the rate of disappearance of alcohol from the blood of dogs given 3 grams of alcohol per kilo. The administration of glucose and insulin reduced the blood alcohol more rapidly. More recently Clark, Morrissey, and Fazekas (12) have shown that the liver of depancreatized cats could not oxidize alcohol in the Warburg apparatus.
In these respects the oxidation of alcohol resembles the oxidation of the acetone substances which disappear from the body when glucose is oxidized. Shaffer (13) found that the antiketogenic effect of glucose could be demonstrated in vitro. When an alkaline solution containing an excess of glucose plus acetoacetic acid was oxidized by hydrogen peroxide, all the acetoacetic acid disappeared. The rate at which the solution lost reducing power and the rate at which the acetoacetic acid disappeared were found to be the same, indicating an interdependence of these two processes. Goldfarb and Bowman (14) have similarly demonstrated that the oxidation of alcohol by $\mathrm{H}_{2} \mathrm{O}_{2}$ in vitro was increased when glucose was simultaneously oxidized.

Both the in vitro and in vivo experiments reviewed above strongly suggest that there is a relation between the oxidation of alcohol and the oxidation of glucose. We are presenting data on the effect of increasing the amounts of glucose oxidized in the body on the alcohol content of the blood in intoxicated human subjects.

\section{METHODS}

The subjects of the experiments were alcoholic patients who had a history of drinking and a definite odor of alcohol on the breath. The degree of intoxication varied widely, and the various types of therapy were used on alternate cases. A blood sample was taken from the antecubital vein on admission and again 2 hours after the therapy was instituted. The following 4 groups of patients were studied: (1) a group in which no therapeutic agent was used; (2) a group treated with 15 units of insulin injected subcutaneously; (3) a group which received 50 cc. of 50 per cent glucose intravenously; and (4) a group treated with both $50 \mathrm{cc}$. of 50 per cent glu- 
cose intravenously and 15 units of insulin subcutaneously.

The blood samples were analyzed by Abel's (15) macro-method. In our laboratory the recoveries of known solutions of alcohol showed an average error of \pm 5.1 per cent. The differences between duplicate analyses of the same blood samples in these experiments never exceeded 10 per cent.

\section{RESULTS}

The data are presented in Tables I and II. Table I compares the observations on the untreated controls and the group injected with 15 units of insulin subcutaneously. It may be seen that the average amount of alcohol which disappeared from the blood in 2 hours was independent of the original blood concentration. In the moderately intoxicated group it was $48 \pm 2.3 \mathrm{mgm}$. per cent, while the severely intoxicated group showed an average reduction of $54 \pm 2.0 \mathrm{mgm}$. per cent. This difference was not significant.

TABLE I

Observations on untreated patients, and those injected with 15 units of insulin subcutaneously (milligrams per cent of alcohol)

\begin{tabular}{|c|c|c|c|c|c|c|c|}
\hline \multicolumn{4}{|c|}{ Control observations } & \multicolumn{4}{|c|}{$\begin{array}{l}\text { Patients injected with } \\
15 \text { units of insulin }\end{array}$} \\
\hline 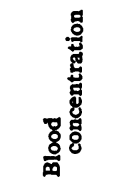 & 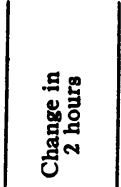 & 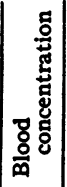 & 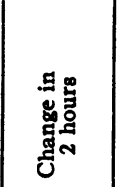 & 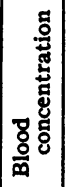 & 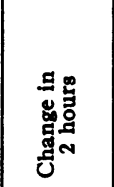 & 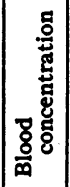 & 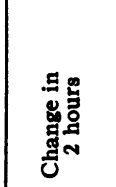 \\
\hline $\begin{array}{r}275 \\
275 \\
275 \\
275 \\
274 \\
237 \\
230 \\
225 \\
206 \\
200 \\
200 \\
200 \\
187 \\
166 \\
150 \\
150 \\
125 \\
90\end{array}$ & $\begin{array}{l}45 \\
69 \\
75 \\
50 \\
60 \\
50 \\
54 \\
75 \\
59 \\
66 \\
50 \\
34 \\
24 \\
46 \\
37 \\
42 \\
35 \\
35\end{array}$ & $\begin{array}{l}\mathbf{6 0 0} \\
\mathbf{5 5 0} \\
\mathbf{5 2 5} \\
\mathbf{5 0 0} \\
\mathbf{4 0 0} \\
\mathbf{3 4 7} \\
\mathbf{3 2 5} \\
\mathbf{3 2 5}\end{array}$ & $\begin{array}{l}75 \\
50 \\
50 \\
50 \\
53 \\
52 \\
51 \\
\mathbf{5 0}\end{array}$ & $\begin{array}{l}280 \\
250 \\
250 \\
250 \\
200 \\
175 \\
125\end{array}$ & \begin{tabular}{|r}
102 \\
61 \\
67 \\
50 \\
40 \\
25 \\
25
\end{tabular} & \begin{tabular}{|l|}
$\mathbf{5 7 5}$ \\
$\mathbf{5 2 5}$ \\
$\mathbf{5 2 5}$ \\
$\mathbf{5 2 5}$ \\
$\mathbf{4 2 5}$ \\
$\mathbf{4 2 5}$ \\
$\mathbf{3 2 5}$ \\
$\mathbf{3 0 0}$ \\
$\mathbf{3 0 0}$
\end{tabular} & $\begin{array}{l}50 \\
50 \\
50 \\
75 \\
50 \\
50 \\
50 \\
86 \\
20\end{array}$ \\
\hline $\begin{array}{l}\text { Average } \\
\text { Differenc } \\
\text { trol }\end{array}$ & $\begin{array}{l}48 \pm 2.3 \\
\text { from cc }\end{array}$ & & $54 \pm 2.0$ & & $\begin{array}{r}53 \pm 6.7 \\
5 \pm 7.1\end{array}$ & & $\begin{array}{r}53 \pm 3.8 \\
1 \pm 4.3\end{array}$ \\
\hline
\end{tabular}

TABLE II

Observations on patients treated with $50 \mathrm{cc}$. of 50 per cent glucose, and with glucose plus 15 units of insulin

(milligrams per cent of alcohol)

\begin{tabular}{|c|c|c|c|c|c|c|c|}
\hline \multicolumn{4}{|c|}{50 cc. of 50 per cent glucose } & \multicolumn{4}{|c|}{ Glucose plus insulin } \\
\hline 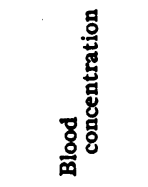 & 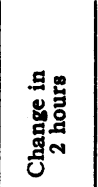 & 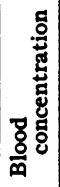 & 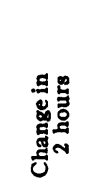 & 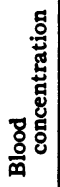 & 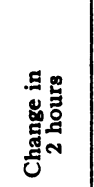 & 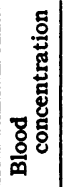 & 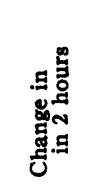 \\
\hline $\begin{array}{l}280 \\
275 \\
254 \\
250 \\
250 \\
250 \\
250 \\
225 \\
212 \\
200 \\
200 \\
175\end{array}$ & $\begin{array}{l}26 \\
25 \\
66 \\
38 \\
50 \\
50 \\
50 \\
50 \\
45 \\
75 \\
55 \\
60\end{array}$ & $\begin{array}{l}600 \\
525 \\
525 \\
500 \\
450 \\
400 \\
350 \\
325 \\
315 \\
300\end{array}$ & $\begin{array}{r}100 \\
75 \\
125 \\
175 \\
135 \\
100 \\
100 \\
115 \\
125 \\
50\end{array}$ & $\begin{array}{l}275 \\
250 \\
250 \\
250 \\
200 \\
180 \\
125 \\
150 \\
105\end{array}$ & $\begin{array}{r}100 \\
175 \\
87 \\
88 \\
91 \\
64 \\
50 \\
57 \\
80\end{array}$ & \begin{tabular}{|l|}
600 \\
600 \\
550 \\
525 \\
500 \\
450 \\
425 \\
425 \\
380 \\
375 \\
350 \\
330 \\
320 \\
300 \\
300
\end{tabular} & $\begin{array}{r}200 \\
275 \\
225 \\
125 \\
200 \\
150 \\
150 \\
232 \\
205 \\
125 \\
125 \\
80 \\
195 \\
140 \\
75\end{array}$ \\
\hline $\begin{array}{l}\text { Average } \\
\text { Difference } \\
\text { from con- } \\
\text { trol }\end{array}$ & $\begin{array}{r}49 \pm 3.0 \\
1 \pm 3.7\end{array}$ & & $\begin{array}{r}110 \pm 7.4 \\
56 \pm 7.6\end{array}$ & & $\begin{array}{l}86 \pm 7.4 \\
38 \pm 7.8\end{array}$ & & $\begin{array}{l}167 \pm 9.7 \\
113 \pm 9.7\end{array}$ \\
\hline
\end{tabular}

Therapy with 15 units of insulin had no effect on the disappearance of alcohol from the blood. Both groups had an average fall of blood alcohol of $53 \mathrm{mgm}$. per cent and statistical analysis revealed that the differences from the controls were not significant.

Table II is a summary of the patients injected with $50 \mathrm{cc}$. of 50 per cent glucose intravenously, and those injected with the glucose plus 15 units of insulin. Patients whose blood alcohol concentration was less than $300 \mathrm{mgm}$. per cent showed an average reduction of $49 \pm 3.0 \mathrm{mgm}$. per cent after treatment with glucose. This was not significantly different from the control group. The more severely intoxicated group treated with glucose had an average reduction of blood alcohol of $110 \pm 7.4 \mathrm{mgm}$. per cent, a statistically significant increase over the control group. Treatment with glucose and insulin resulted in a greater fall in blood alcohol in both the moderately intoxicated as well as the severely intoxicated patients. The average reduction was $86 \pm 7.4 \mathrm{mgm}$. per cent and $167 \pm 9.7 \mathrm{mgm}$. per cent in the 2 groups respectively.

The clinical appearance of the patients treated with the various types of therapy presented marked differences. Patients who were injected 
with 15 units of insulin alone invariably showed slight sweating, and a fall in temperature. Those who were mentally clear frequently complained of feelings of hunger about 2 to 3 hours after the injection. No significant changes were noted in the group treated with glucose alone. The patients treated with glucose and insulin recovered consciousness between $11 / 2$ to 2 hours after treatment, and in some cases showed adequate motor coordination within 4 to 5 hours. In most of these cases a rational history could be obtained at the end of 2 hours.

\section{DISCUSSION}

The oxidation of alcohol is of interest both from the purely physiological as well as the clinical points of view. Most investigators have found that the oxidation of ingested alcohol is accelerated when food, especially carbohydrate, is simultaneously oxidized. In a previous publication we have shown that the oxidation of alcohol in vitro is in some way accelerated when glucose was oxidized in the same solution. This analogy, although suggestive, cannot be taken as proof, since the oxidative processes involved in no way resemble those in the animal organism.

We found that the administration of glucose alone had a moderate effect on the rate of disappearance of alcohol in the severely intoxicated patients, while the moderately intoxicated group showed no change from the controls. It was suggested that the alcoholic patients were in various states of undernutrition and could not oxidize the glucose given. This seemed probable in view of the fact that Traugott (16) found that as little as a 3-day fast produced a marked diminution of sugar tolerance in humans. We have examined the sugar tolerance in a group of patients similar to those reported in this paper. In most cases there was an abnormal elevation of the tolerance curve, with a return to normal when they were tested one week later. During the week the patients were maintained on a normal hospital diet (17). It is therefore likely that the glucose alone did not accelerate the oxidation of alcohol in most cases because the glucose was not oxidized. The addition of insulin assures the oxidation of the glucose, and the oxidation of the alcohol in the body is thus accelerated.
The prognosis of acute alcoholism is ordinarily very good for recovery, and patients usually receive very little active therapy. However, fatalities have been reported, and any patient who reaches the stage of alcoholic coma may be considered dangerously ill. Therapy should be aimed at a reduction of the alcohol content of the body. Robinson and Selesnick (4) increased the excretion through the lungs by increasing the respiratory volume with 10 per cent carbon dioxide in oxygen. They were able to produce a reduction of blood alcohol ranging from 8 to 137 mgm. per cent in $1 / 2$ hour in severely intoxicated patients. In the present experiments the administration of glucose and insulin caused a reduction of blood alcohol ranging from 75 to 275 mgm. per cent in 2 hours in a comparable group of patients. This therapy is of advantage over carbon dioxide and oxygen in that no special apparatus is required, and the immediate attendance of the physician is only necessary for a few minutes.

\section{CONCLUSION}

We have determined the effect of the glucose and insulin on the rate of disappearance of alcohol from the blood of intoxicated patients.

1. The injection of $\mathbf{1 5}$ units of insulin had no effect on the blood alcohol.

2. The injection of $50 \mathrm{cc}$. of 50 per cent glucose intravenously caused a moderately increased fall in blood alcohol only in the severely intoxicated patients. No change was observed in the less severely intoxicated patients.

3. The administration of both glucose and insulin accelerated the decrease in blood alcohol in all patients. It is suggested that the oxidation of alcohol may be catalyzed by the simultaneous oxidation of glucose.

\section{BIBLIOGRAPHY}

1. Sollmann, T. H., Manual of Pharmacology. W. B. Saunders Co., Philadelphia, 1926, 3rd ed., pp. 654 698.

2. Atwater, W. O., and Benedict, F. G., An experimental inquiry regarding the nutritive value of alcohol. Mem. Nat. Acad. Sc., 1902, 8, 231.

3. Haggard, H. W., and Greenberg, L. A., Studies in absorption, distribution, and elimination of ethyl alcohol. ... J. Pharmacol. \& Exper. Therap., 1934, 52, 137. 
II. Excretion of alcohol in urine and expired air; and distribution of alcohol between air and water, blood and urine. Ibid., 1934, 52, 150.

III. Rate of oxidation of alcohol in body. Ibid., 1934, 52, 167.

4. Robinson, L. J., and Selesnick, S., Treatment of acute alcoholism, with 10 per cent carbon dioxide and 90 per cent oxygen inhalation. J. A. M. A., 1935, 105, 1734.

5. Mellanby, E., Alcohol: its absorption into and disappearance from the blood under different conditions. Medical research council (Gt. Brit.), Special Report Series No. 31, 1919.

6. Southgate, H. W., The effect of alcohol, under varying conditions of diet, on man and animals, with some observations on the fate of alcohol in the body. Biochem. J., 1925, 19, 737.

7. Widmark, E. M. P., Studien über den Einfluss vershiedener Nahrungsbestandteile auf den Äthylalkoholgehalt des Blutes. Biochem. Ztschr., 1934, 270, 297.

Uber die Einwirkung von Aminosäuren auf den Alkoholgehalt des Blutes. Ibid., 1933, 265, 237.

Der Einfluss der Nahrungsbestandteile auf den Alkoholgehalt des Blutes. Ibid., 1933, 267, 135.

8. Tögel, O., Brezina, E., and Durig, A., Ueber die Kohlenhydratsparende Wirkung des Alkohols. Biochem. Ztschr., 1913, 50, 296.
9. Brechmann, H. J., Respirationsversuche nach Aufnahme von Fruchtzucker, Traubenzucker und Alkohol sowohl während der Ruhe als auch während der Arbeit. Ztschr. f. Biol., 1927, 86, 447.

10. Bornstein, A., and Loewy, A., Untersuchungen über den Alkolholumsatz beim Menschen. Biochem. Ztschr., 1927, 191, 271.

11. Clark, B. B., and Morrissey, R. W., Influence of insulin, glucose and alkalizing salts on the rate of disappearance of ethyl alcohol from the blood. Amer. Jour. Physiol., (proc.), 1938, 123, 37.

12. Clark, B. B., Morrissey, R. W., and Fazekas, J. F., Insulin and oxidation of ethyl alcohol by excised diabetic liver tissue. Science, 1938, 88, 285.

13. Shaffer, P. A., Antiketogenesis, An in vitro analogy. J. Biol. Chem., 1921, 47, 433.

14. Goldfarb, W., and Bowman, K. M., The effect of glucose on the oxidation of alcohol in vitro. Proc. Soc. Exper. Biol. and Med., 1938, 39, 471.

15. Abels, J. C., Simple method for determinaton of ethyl alcohol in blood. Proc. Soc. Exper. Biol. and Med., 1936, 34, 346.

16. Traugott, $K$., Ueber das Verhalten der Blut zuckerspiegels bei wiederholter und verschiedener Art enteraler Zucker zufuhr und dessen Bedeutung für die Leberfunktion. Klin. Wchnschr., 1922, 1, 892.

17. Bowman, K. M., Orenstein, L., Wortis, J., and Goldfarb, W., The sugar tolerance in alcoholics. Proc. Soc. Exper. Biol. and Med., 1939 (In press). 